\title{
URBAN GEOCHEMICAL MAPPING STUDIES: HOW AND WHY WE DO THEM
}

Christopher C Johnson

E Louise Ander

British Geological Survey

Keyworth, Nottingham. NG12 5GG

\section{Abstract}

Geochemical mapping is a technique rooted in mineral exploration but now has found worldwide application in studies of the urban environment. Such studies, involving multi-disciplinary teams including geochemists, have to present their results in a way that non-geochemists can comprehend. A legislatively driven demand for urban geochemical data in connection with the need to identify contaminated land and subsequent health risk assessments has given rise to a greater worldwide interest in the urban geochemical environment. The aims and objectives of some urban studies are reviewed and commonly used terms such as baseline and background are defined. Geochemists need to better consider what is meant by the term "urban". Whilst the unique make up of every city precludes a single recommended approach to a geochemical mapping strategy more should be done to standardise the sampling and analytical methods. How (from a strategic and presentational point of view) and why we do geochemical mapping studies is discussed.

\section{Introduction}

Geochemical mapping is a technique developed in the 1950s to give information on the spatial distribution of chemical elements and compounds at the Earth's surface. Its origins go back to the Soviet Union (Fersman, 1939) and subsequently applied elsewhere for the purposes of mineral exploration, for example Lovering et al. (1950) and Hawkes \& Bloom (1955). Regional mapping also found application to issues concerning the environment and health (e.g. Thornton \& Webb, 1979 and Plant \& Moore, 1979). Regional geochemical maps are considered to be a national asset for resource evaluation and environmental management and many national surveys have been undertaken around the world, for example, Johnson et al., 2005 (United Kingdom); Muchsin et al., 1997 (Sumatra, Indonesia); Sewell, 1999 (Hong Kong); Reimann et al., 1998 (Barents Region); Vrana et al., 1997 (Slovak Republic) and recently on a continental scale Salminen et al., 2005, (Europe). Procedures for regional geochemical mapping are now well established and recommended guidelines documented (Darnley et al., 1995). 
These regional geochemical mapping surveys, particularly ones conducted before the 1990s, generally avoided urban areas as their principal aim was one of mineral exploration. Surveys avoided the anthropogenic contamination so as to better attribute anomalies to nature's own form of "natural contamination", namely metalliferous mineralisation. The British Geological Survey's (BGS) Geochemical Baseline Survey of the Environment (G-BASE) Project illustrates this point well. Regional geochemical samples were collected from Scotland mainly during the 1970s but not from large urban areas such as Glasgow. As a result there was an empty region in the data for the city of Glasgow, surrounded by a halo of high heavy metal concentrations (Figure 1) which at the time was attributed to diffuse pollution around the city. It was not until 2001 that the city of Glasgow was systematically sampled (Fordyce et al., In Prep).

In the 1980s there was a growing awareness of health risks in urban areas that could be related to the contamination of the environments. For example, the Environmental Geochemistry Research Group at Imperial College, London, built on its expertise in geochemical mapping and became involved in projects examining sources, processes and effects for some heavy metals (Thornton et al., 1994). Increased environmental awareness and the increased funding for such work, connected with a decline in exploration interest in developed countries, led to more geochemical mapping studies being done in urban areas.

A legislatively driven demand for urban geochemical data in connection with the need to identify contaminated land and subsequent health risk assessments has given rise to a greater worldwide interest in the urban geochemical environment. Examples of such investigations are listed in Table 1; this does not seek to be a comprehensive list of all surveys done but a representative selection that indicates the methodology in use along with the aims and objectives of such investigations. The importance of knowing this contextual data is discussed later.

\section{Review of urban geochemical mapping studies}

A literature search for papers on urban geochemical mapping reveals how in the last decade there have been an increasing number of environmental and geochemical 
studies of urban areas. Studies of urban areas from Europe predominate with an increasing number of studies reported from Asia in recent years. This is probably a reflection of the fact that many cities of Europe have inherited a long industrial history and an associated legacy of contamination. A similar summary from a trace element perspective is reported in the review of Wong et al. (2006). This review also has a discussion of the development of the discipline of Urban Environmental Geochemistry and attributes the term "urban geochemistry" to Thornton used to describe research activities concerning the role of the geochemist at the interface of environmental geochemistry and urban pollution (Thornton, 1991).

Wong et al. (2006) show that $\mathrm{Pb}$ continues to be one of the most studied and reported elements. Other potentially toxic elements (PTE) such as $\mathrm{As}, \mathrm{Cd}, \mathrm{Cr}, \mathrm{Cu}, \mathrm{Ni}$, and $\mathrm{Zn}$ also commonly feature in urban geochemical mapping. Analytical techniques are used that produce multiple element determinations for a single sample, e.g. X-ray fluorescence spectrometry (XRFS), inductively coupled plasma atomic emission spectrometry (ICP-AES) or inductively coupled plasma mass spectrometry (ICP-MS). However, such methods, depending on what (if any) extraction technique is used, will give results of varying value according to the strength of the extraction and predominant mineralogical characteristics of the sample. This is of fundamental importance to end users of the data who, for example, may wish to know how bioaccessible a particular element is. Certain elements such as $\mathrm{Hg}$ and $\mathrm{Se}$, although as important as the previously mentioned PTEs, are less frequently reported simply because the analytical methodology requires greater effort and thus expense. Similarly organic compounds, although of equal if not greater importance to the quality of the urban environment, are less frequently reported because researchers with traditional links to regional and exploration mapping do not have the experience, facilities or budget to tackle the more complex field of organic analysis.

Table 1 shows many common aims and objectives, including:

- establishing a baseline for the urban environment

- satisfying the legislative-driven demand for geochemical information on the urban chemical environment

- identifying/locating polluted areas 
- assess the contribution of parent materials and anthropogenic activity to the geochemical baseline

- assess risks to other compartments of the urban environment (e.g. groundwater)

- identify sources of PTEs

There is diversity in the detailed sampling and analytical methodologies, which has consequences when it comes to comparing urban baselines (see later discussion). These are issues such as the defined depth for a topsoil and the method of compositing samples at a single site to give a more "representative" sample.

Studies can be classified into one of two categories namely systematic urban mapping or targeted urban mapping. The characteristics of each class are generalised and summarised in Table 2. Systematic surveys usually provide the catalyst and resources for subsequent targeted studies and are more constrained as to what sample media they can use. If they cover an entire urban area the sample media has to be something that is found everywhere and if the urban area is to be placed in the context of a region then it should be the same as that which the regional survey has used. Soils are probably the most ubiquitous of sample media and are most frequently used in urban surveys. The final point of the summary table considers the type of organisation likely to carry out such a survey. This is very much linked to who finances the investigation. Finding funding for an urban survey can be every bit as challenging as agreeing on the scientific methodology. The funding process is made more complicated because urban studies require a multi-disciplinary approach and it is very difficult coordinating the funding across a diversity of organisations.

There is a whole area of data not covered by the classification of Table 2 or considered in the summary of Table 1, namely commercial site survey reports. These are produced by consultants and are generally only seen by the customers. These too generate geochemical information but much of this information is considered confidential and never gets further than the client.

There is also a terminology used in urban geochemical mapping that to nongeochemists would appear confusing and even amongst geochemists themselves evokes a divergence of opinions. A feature of urban environmental studies is the 
inherent multi-disciplinary approach involving, in addition to geochemists, health workers, social scientists, policy makers, city planners and administrative authorities. It is important that as geochemists we use our terminology with clarity and consistency.

\section{Some Definition of Terms}

Urban area. We can envisage our environment in terms of two end-points on a line. At one end we have the idea of a pristine environment totally unaffected by human activity - there can be few places on earth that are actually in this state (Yin et al. 2006). At the other end-point we have intense anthropogenic activity that has a likelihood of leading to contamination. All regions of the earth can be plotted on this line with urban areas lying towards the contaminated end point. As geochemical sampling strategies for urban and rural areas will be different it is important that geochemists have a means of defining what an urban area is. A search of the internet reveals a great range of definitions and one can only conclude that there is no single definition that meets the needs of all users. Social scientists tend to use population numbers or population density to define urban areas though thresholds will vary from country to country. In the United Kingdom one definition of an urban area is a settlement having a population $>10,000$ (Countryside Agency, 2004). The US Census Bureau defines urbanised areas as having a population > 50,000 (US Census Bureau, 1995).

Few of the studies listed in Table 1 give their criteria for defining urban areas. Physical scientists generally approach definitions of urbanisation from the standpoint of the built environment (Long et al., 2001). The UK Soil and Herbage Pollutant Survey (Wood et al., 2007) define urban as being an area which is $\geq 90$ per cent urbanised/built up though offers no explanation as what is meant by urbanised or built up. A similar method of using built up areas to define an urban area is employed by the G-BASE project (see Figure 2 ). The "built up" ornament on the 1:50,000 scale (UK) Ordnance Survey topographic maps is used to define the urban boundary.

In some instances the urban boundary may simply be an administrative one and projects are constrained to working with this boundary because collaborating partners (e.g. a city council) are restricted to working within it. 
Urban boundaries tend to be transitional and generally move outwards over relatively short periods of time as settlements grow so it is important to put urban definitions into a historical context. Metropolitan areas, conurbations, urban clusters, urban centres are terms that are used loosely and should be used with care as they have a more specific meaning than the more general term of "urban area". In urban geochemical mapping studies it is important to target areas where there has been some degree of associated anthropogenic activity. Such areas might include extra-urban industrial sites which can be considered as a "built up" area but where resident population is absent or very low. Purely industrial sites could be classified as a separate category to urban sites as was done in the UK soil and herbage pollutant survey (Woods et al., 2007).

It would not be helpful for geochemists to work to a single definition of an urban area. Every human settlement has its own unique set of characteristics which will give rise to a unique geochemical baseline. The important thing is that urban geochemical studies report the criteria used (as discussed above) to define the spatial extent of the investigation.

Geochemical Baseline. The term geochemical baseline is now in widespread use in the geochemical literature. This is a reflection of the shift away from geochemical mapping's previously principal use in mineral exploration to environmental applications. The processes driving the need for geochemical baselines are described in global initiatives such as the FOREGS (Forum of European Geological Surveys) European geochemical baseline project (Plant et al., 1997, and Salminen et al., 1998). The International Geological Correlation Programme (IGCP) Project 259 "The global geochemical database for environmental and resource management" (Darnley et al., 1995) ended in 1994 and was succeeded by IGCP Project 360. For the IGCP project internationally agreed protocols and procedures for geochemical baseline mapping were developed. Salminen \& Tarvainen (1997) attribute the official introduction of the term geochemical baseline to the IGCP 360 project. However, as discussed by Salminen \& Gregorauskiene (2000), the term geochemical baseline was not well defined. 
Tidball et al. (1974) used the term baseline in connection with sagebrush and soils from Montana Wyoming, USA and this was a statistical definition based on the central $95 \%$ of recorded values. Another earlier use of the term baseline in the context of geochemical mapping is that of Davenport et al. (1993) applied to geochemical mapping in Newfoundland and Labrador as a measurement of environmental change.

The following definition of a geochemical baseline is based on that used by the Forum of European Geological Surveys (FOREGS) Geochemical Baseline Mapping Group:

\section{"A Geochemical baseline is the concentration at a specific point in time of a} chemical parameter (element, species or compound) in a sample of geological material. It is a fluctuating surface rather than a given value”.

The geochemical baseline of element/compound $\mathrm{X}$ can be defined as a function of the methodology used to determine it:

\section{Baseline $X=f\{A, B, C, D\}$}

for 1 to $\mathrm{n}$ samples from different locations at a specified point in time where $\mathrm{A}$ is a defined media type, $\mathrm{B}$ a documented sampling method, $\mathrm{C}$ a documented sample preparation protocol, and $\mathrm{D}$ a documented analytical method.

Defining the baseline as a function in this way emphasises the need to standardise methodologies. One baseline can only be truly compared with another if all the methods used are the same. However, there are techniques that can be used to level and normalise one baseline data set with another (Darnley et al., 1995). The UK G-BASE project has been baseline mapping since the late 1960s during which time analytical methods have changed, yet the project is still able to produce a seamless geochemical baseline for regional and urban areas as a result of its data conditioning procedures (Johnson et al., 2005 and Johnson et al., In Press).

The geochemical baseline is defined at a specific point in time. For regional geochemical mapping in areas of little anthropogenic activity, with the exception of catastrophic events such as volcanic eruptions or extensive flooding, the baseline changes slowly in response to natural changes in an order of magnitude of decades or centuries. Changes to the urban geochemical baseline as a result of constant 
anthropogenic activity would be anticipated as being more rapid so the time component is a more important factor.

The formal definition of a baseline makes the concept appear more complicated than it is. A geochemical baseline simply reports the chemical state of the surface environment exactly as it is with no interpretation or partitioning of the data. A baseline is often qualified by a term based on the sampling medium or region of sampling, e.g. urban soil geochemical baseline or regional stream sediment geochemical baseline.

Background. Another frequently used term is geochemical background, a term familiar to those with experience in geochemical exploration in which it was important to partition the geochemical baseline into a background and anomaly. In the context of the urban environment the geochemical background can be defined as:

"A relative measure to distinguish between natural element or compound concentrations and anthropogenically-influenced concentrations in real sample collectives" (Matschullat et al., 2000). This can be expressed as a simple equation:

\section{BASELINE $=$ BACKGROUND + Anthropogenic Contribution}

This is a simplification because the background may be made up of many contributing geochemical populations (caused by variations in underlying parent material, for example) and the anthropogenic contribution can also be from multiple sources. Definition of the background enables us to quantify the urban contamination. (see later section). Background, unlike a baseline, is determined by interpreting or modelling the data.

Guideline or Intervention values. Urban geochemical mapping studies will often put their data for potentially toxic elements or compounds in the context of guideline or intervention values in order to delineate areas where there is a potential risk to health. In the UK Contaminated Land Exposure Assessment (CLEA) soil guideline values (SGV) (DEFRA-EA, 2002a) are now often cited (see Table 3). Other guideline/intervention values are cited for other countries as part of legislation for identifying contaminated land that might pose a risk to health (cite Jaana Java's New 
Orlean's SEGH presentation if in this volume). SGVs represent an intervention value which if exceeded indicate potentially unacceptable risks to site users. If the SGVs are exceeded then this might suggest that further investigations and/or remedial action may be required to protect human health. Such guideline or intervention values are determined by establishing authoritative health criteria values for each contaminant through a review of scientific literature.

\section{How we do Urban Geochemical Mapping Studies}

Table 1 gives an indication of the methods used for urban geochemical mapping and more details of methodology can be found in the cited references. This section on how we do geochemical mapping studies is more concerned with strategy and presentation than the details of methods. In connection with strategy, the first point that must be emphasised is that no two urban areas are the same and any strategy for mapping an urban area must consider the history of urbanisation and industrialisation in addition to its geographical setting. Opportunities for soil sampling in an intensively built up area such as Hong Kong will be far fewer than say in Nottingham (UK) where houses are more likely to have gardens. Similarly, a shallow dry stony soil, say from a Mediterranean region, will be more easily collected with a trowel or spade than a well developed soil from the northern temperate zone that can easily be collected with a $1 \mathrm{~m}$ soil auger. Whilst it is useful to have a generic guide to geochemical mapping (Darnley et al. 1995), methodology for urban areas cannot be too prescriptive in order to account for the diversity of conditions that go into the make up of an urban environment.

Whilst it may be difficult to compare urban areas on a continental scale it is desirable to be able to compare them on a national scale. Any strategy for sampling an urban area must be designed with the end users of the data in mind. For example, if the urban baseline is to be used to define contaminated land that poses a risk to health then the geochemical baseline mapping should use the same sample media and analytical methodology that has been used to define the legislative guideline values. There is little point using, for example, roadside dust determined following a weak acid extraction if health risks have to be put into the context of soil guideline values for total element concentrations. Conversely, it is an important role of targeted 
geochemical mapping to highlight the inappropriateness of guideline/intervention values based on total element concentrations when it is the bioaccessible fraction of an element that may be more important when considering the impact on human health.

This section opened with a statement that recommendations for urban geochemical mapping should not be too prescriptive on account of the diversity of urban make up particularly on a continental scale. However, there is a need for guidelines on how to conduct urban sampling and subsequent chemical analyses. Table 1 summarises some of the more important aspects of the methodologies and these are categorised as follows.

\section{Sampling and Analytical Strategy}

Sample Media. Soil is the most widely used sample media particularly for systematic sampling of complete urban areas. As many targeted studies have been in connection with vehicle pollution, roadside dust is also a frequently reported sample medium. Drainage sediments are not as widely used as in non-urban studies mainly on account of their artificial and inaccessible nature (e.g. underground water culverts) in built-up environments. Studies that have used drainage sediments (e.g. Fordyce et al. 2004) are able to better consider movement of contaminants between the different urban environmental compartments. Tree bark and attic/house dusts (e.g. Tye et al. 2006) can be used for targeted studies involving atmospheric transport of contaminants. Atmospheric levels of elements and compounds are rarely reported in geochemical journals and research tends to be done by other disciplines. This point illustrates the need for greater inter-disciplinary cooperation particularly in studying the movement of chemicals and compounds between the different compartments of the urban environment which will be represented by different sample media.

Soil Sampling Depth. Urban soil sampling tends to use a depth rather than horizon based approach on account of the poor development of soil horizons in many urban soils. Surface soils or "topsoils" are generally collected from $0-10 \mathrm{~cm}$ but may or may not include the surface organic litter or root zone. "Deep" or "Profile" soils are generally collected from $>35 \mathrm{~cm}$ usually for the purpose of establishing a relationship with parent material or using results in the context of a regional baseline. 
Soil Fraction. Use of the $<2 \mathrm{~mm}$ fraction of soil samples is now widespread, although some studies have reported finer fractions mainly to be consistent with earlier regional work. Gentle disaggregation of samples to make sure fine particles are not lost because they are aggregated is an essential part of the sample preparation process, and may make a significant difference to results if not carried out.

Soil Representativity. It is generally accepted that the origin and history of urban soils leads to a greater heterogeneity than in non-urban areas and sampling strategies usually involve sampling at a higher density to capture more of the between site variability. In order to deal with "within site" variability most investigations will create a composited sample though procedures vary both in the number of composite samples (generally 3 to 9 sub-samples) or the area and shape of sampling zone (see Table 1).

In urban areas the G-BASE project collects four duplicate pairs (i.e. eight samples) from every one hundred sites and these are split in the laboratory to give replicates. Using nested ANOVA analysis the variance "between sites", "within sites" and "within samples" can be quantified (Johnson et al., In Press). A successful sampling and analytical strategy would expect at least $80 \%$ of the variance to be attributed to "between sites" (Ramsey et al. 1992). It is important that urban studies should quantify variance for each analyte in this way, particularly studies collecting small amounts of material, say for example in soils over a very restricted (several centimetres) depth of sampling.

A nested sampling investigation by the G-BASE project to look at the optimum soil sampling density (Rawlins \& Brown, 2002) has also provided information on element variance captured over varying distances. This work showed that elements associated with anthropogenic contamination require shorter sampling intervals to capture their variance than do the geogenic elements (that is those elements associated with the underlying parent material).

Sample Analysis. The most significant divergence in reporting geochemical data from urban areas relates as to whether results are total analyses (XRFS or neutron activation (NA)), near total (four acid attack (Hydrofluoric Acid (HF), Perchloric Acid $\left(\mathrm{HClO}_{4}\right)$, Nitric Acid $\left(\mathrm{HNO}_{3}\right)$ and Hydrochloric Acid $\left.(\mathrm{HCl})\right)$ during extraction 
procedure), or partial (great variety of methods designed to identify various components of a total analyses, particularly relating to bioaccessibility). It is very important that the method of analysis is borne in mind when comparing urban baselines and when the data is placed in the context of guideline/intervention values.

\section{Presenting Baseline Data}

An important component of urban geochemical mapping studies is how we present our baseline data. The increasing number of urban investigations has coincided with a period of growth in the power of desktop computing and the availability of more userfriendly Geographical Information System (GIS) software applications such as ArcGIS and MapInfo. An important outcome of urban geochemical studies is a GIS project in which the multi-disciplinary components can be represented in the different layers and readily interrogated. The GIS is dependent on a well constructed and quality controlled digital data set. The importance of geochemical databases cannot be underestimated, they enforced a high degree of data standardisation and preserve the results for use in future investigations. The G-BASE project contributes its results to the corporate BGS Geochemistry Database (Coats \& Harris, 1995), a database containing some half-a-million samples and eight million analyte determinations. Given that a geochemical sample costs something between US $\$ 100-\$ 200$ to collect, prepare and analyse such a database is an asset of considerable value.

In publications the baseline data can simply be presented as a table of data or more satisfactorily as a geochemical map or interpolated image. A baseline is data presented with the minimum of interpretation and the interpolated geochemical images such as that shown in Figure 1 based on a percentile classification is a common form of presentation. Care has to be taken in the presentation of geochemical data for urban areas as lack of understanding as to what an interpolated images shows can lead to property being blighted unreasonably particularly if inappropriate gridding parameters have been used. For this reason the G-BASE project prefers to present baseline geochemical data for urban areas as classified symbol maps (Figure 3) and it is repeatedly emphasised that the nature of the survey is one of investigating regional trends rather than site specific investigations. 
Baseline data can be informatively presented in a graphical manner and techniques used to give visual comparisons between different urban baselines. Histograms, box and whisker plots (Figure 4) and cumulative frequency probability plots are a few examples (Figure 5). The box and whisker plot can be used to classify baseline data (e.g. by underlying parent material) to aid interpretation. The cumulative frequency probability plot (Sinclair, 1976) is particularly informative because it not only gives an immediate visual impression of the data range and multi-modal distribution but it can also be used to partition data to establish background and contaminated areas.

\section{Why we do urban Geochemical Mapping Studies}

According to the 2005 revision of the United Nations World Urbanisation prospects report (UN, 2006) 3.2 billion people lived in urban areas in 2005, a figure which will grow by 2008 to surpass to world's rural population. Sixty percent of the world's population is expected to live in cities by 2030 . In developed countries with a history of urbanisation and industrialisation going back many centuries the percentage of urban population is higher, as is the legacy of industrial contamination. This legacy arose from times when we were unaware as to the many health impacts of urbanisation combined with an attitude that economic development was more important than the quality of life and health of the population. It is because we now live in more enlightened times in which we and responsible governments are concerned about our health, the quality of our lives and environmental sustainability that we do urban geochemical mapping studies.

The American Minerals Information Institute ${ }^{1}$ estimates that every American will need 3.7 million pounds $\left(1.68 \times 10^{6} \mathrm{~kg}\right)$ of minerals, metals and fuels during their lifetime. If one imagines several generations and ponders where the materials come from, where they are processed and where they are used and disposed of, then it is no surprise that anthropogenic activity significantly modifies the chemical environment of urban areas.

Urban areas are associated with many problems that impact on human health and life. Why should resources be spent on doing geochemical mapping when, say for

\footnotetext{
${ }^{1}$ www.mii.org
} 
example, a bigger priority might be preventing people getting run over and killed by cars on city street? Geochemists must be able to justify their reasons for doing such investigations if they are to expect support for their work. Mapping that just shows an urban area is contaminated by anthropogenic activity, something that can easily be predicted, is insufficient reason alone. Outcomes must demonstrate that the work leads to an improvement in the health and quality of life of the local population and a more sustainable local environment.

Part of the problem is a general lack of understanding amongst the general public and those responsible for their urban environment of the impact of the chemical environment on human health and the quality of life. Chemical hazards are not seen in the same way as physical hazards. People notice subsiding buildings, the damage to property through flooding, earthquake and volcanic eruptions, hazards that effect property. They are not so aware of the silent and less visible effects of cancer causing radon and arsenic, or the mental impairment through excessive exposure to lead or mercury or even a lack of iodine in the diet. Chemical hazards impact more directly on people than property so it might be expected that people should be more concerned. Geochemists must learn to communicate the hazards of the chemical environment in a way people can understand. After all, the risks of the chemical environment are more predictable than events such as hurricanes, flooding and earthquakes and more readily mitigated.

Unfortunately, it takes catastrophic events to highlight the importance of knowing the geochemical baseline, events such as the Chernobyl (Ukraine) nuclear accident in 1986, the flooding of New Orleans (USA) in 2005, or the Buncefield oil refinery fire (UK) in 2005. All these events have used pre-event baseline information to assess and understand the post-catastrophe impact. If not a catastrophic event it usually takes legislation before urban authorities believe they have a requirement for geochemical data. There was a significant increase in the licencing of G-BASE baseline data by local authorities following the introduction of the Environmental Protection Act Part IIA (DETR, 2000) in the UK in April 2000.

There is little doubt that some of the pioneering work done by the founders of the Society for Environmental Geochemistry and Health, particularly with regard to lead 
in the urban environment, has resulted in a more healthy urban environment and greater protection of our children from lead poisoning. Geochemical mapping studies will continue to bring new issues to the forefront, e.g. Arsenic and Polychlorinated Biphenyls (PCBs) (Reference to Rolf Ottensen's work in Norway presented at SEGH New Orleans conference if included in this volume).

Targeted urban studies have a role to identify and understand the chemical hazards of our urban environment whilst the systematic studies can help policy makers and legislators to use more appropriate intervention values. By systematic surveying we can identify areas at risk that otherwise would not have been predicted (e.g. contaminated fenland in NW England, Breward (2004)). Systematic surveys also have the potential to estimate levels of diffuse pollution added to the urban environment through anthropogenic activity (Rawlins et al., 2005) and can demonstrate anthropogenic impact by subtracting the extra-urban baseline (used to define natural background) away from the urban baseline (Tarvainan et al., 2006 or Jaana Java's New Orlean's SEGH presentation if in this volume).

The purpose of urban geochemical mapping is a long term goal to understand and improve our knowledge of the urban environment rather than to have short-term outcomes. A cost benefit analysis would demonstrate that the money saved nationally on the need to inappropriately remediate land defined as contaminated by poor legislation would far outweigh the cost of carrying out a national urban geochemical survey. Such mapping provides the information to give more appropriate guideline/intervention values. For example, the UK Association of Geotechnical and Geoenvironmental Specialists (AGS) estimate that over a fifteen year period (20012016) remediation of brownfield sites is likely to cost within the range $£ 2$ billion to $£ 6.75$ billion (US $\$ 4$ to US \$13.5billion) (AGS, 2006). A substantial proportion of the sites where remediation is taking place fall into the category where concentrations of toxic compounds such as lead and arsenic fall slightly above the SGV. A significant cost for risks that might be considered tolerable or minimal. 


\section{Conclusions}

1. Geochemical studies of urban environments have grown in importance relative to the historical application of geochemical mapping to mineral exploration.

2. The last decade has seen an increase in urban geochemical mapping particularly in Europe where a long industrial history has left a legacy of contamination in many cities.

3. Whilst the diversity of the make up of urban areas worldwide would prevent an overly prescriptive approach to urban geochemical mapping, it is important that there are guidelines more detailed than the generic recommendations of Darnley et al. (1995) to assist in greater standardisation of methodologies in urban studies. An estimation of the anthropogenic contribution to the baseline is more easily done if an urban survey uses the same methods as employed in the regional baseline mapping.

4. Urban geochemical mapping studies can generally be classified as either being systematic surveys or targeted surveys. The former tend to be done by national organisations and will involve 100s or 1000s of samples. The targeted surveys are more likely to be done by university and research institutes.

5. Urban studies require a multi-disciplinary approach and geochemists must learn to communicate their work and results to non-geochemists in a more comprehensible manner. Definitions of what an urban area is, geochemical baseline and background, and guideline/intervention values need to be used with greater clarity.

6. Urban geochemical studies need to have better defined outcomes than just demonstrating that an urban area is contaminated. They should have a long term goal of improving the health, quality of life and sustainability of the environment.

7. It is unfortunate that it takes catastrophic events or legislation to demonstrate the value of baseline geochemical data. Geochemists need to do more to highlight the risks of the chemical environment which are less obvious, though more controllable than physical hazards.

8. Baseline data for urban areas, particularly if used in the context of the regional baseline, can be used to assist policy makers and legislators create better legislation with more appropriate guideline/intervention values. 


\section{Acknowledgement}

This paper is published with the permission of the Director of the British Geological Survey (NERC). The authors grateful acknowledge contributions from other members of the G-BASE project team, particularly Fiona Fordyce and Dee Flight for a critical assessment of this contribution. Unless otherwise stated, BGS (C) NERC. All rights reserved. 2007.

\section{References}

AGS. (2006). Issues of scale and potential impact of SGVs for land remediation. UK Association of Geotechnical and Geoenvironmental Specialists (AGS) "overview" presentation to the Soil Guideline Value Task Force meeting on $13^{\text {th }}$ July 2006. Available at: http://www.ags.org.uk/publications/SGVs.pdf .

Ahmed, F., Bibi, M.H. \& Ishiga, H. (2007). Environmental assessment of Dhaka City (Bangladesh) based on the trace metal contents in road dusts. Environmental Geology, Vol. 51, 975-985.

Al-Khashman, O.A. (2007). Determination of metal accumulation in deposited street dusts in Amman, Jordan. Environmental Geochemistry and Health, Vol. 29, 1-10.

Biasioli, M., Barberis, R. \& Ajmone-Marsan, F. (2006). The influence of a large city on some soil properties and metals content. Science of the Total Environment, Vol. 356(1-3): 154-164.

Birke, M. \& Rauch, U. (2000). Urban geochemistry: investigations in the Berlin metropolitan area. Environmental Geochemistry and Health, Vol. 22, 233-248.

Bityukova, L., Shogenova, A. \& Birke, M. (2000). Urban geochemistry: a study of element distributions in the soils of Tallinn (Estonia). Environmental Geochemistry and Health, Vol. 22, 173-193.

Breward, N. (2003). Heavy-metal contaminated soils associated with drained fenland in Lancashire revealed by BGS Geochemical Survey. Applied Geochemistry, Vol. 18, 1663-1670.

Carrez, F., Taylor, K.G., Stainsby, S. \& Robertson, D. (2006). Contaminated urban road deposited sediment (RDS), Greater Manchester, UK: a spatial assessment of potential surface water impacts. North West Geography, Vol. 6, 10-19.

Coats, J S, \& Harris, J R. (1995). Database design in geochemistry: BGS experience. 25-32 in Geological Data Management. Giles, J R A (editor). No. 97. (Geological Society of London Special Publication.)

Countryside Agency. (2004). Rural and Urban Area Classification 2004: An Introductory Guide. The Countryside Agency, England and Wales. Available as a pdf file from http://www.statistics.gov.uk/geography/downloads/Introductory Guide.pdf

Darnley, A.G., Bjorklund, A., Bolviken, B., Gustavsson, N., Koval, P.V., Plant, J.A., Steenfelt, A., Tauchid, M., \& Xuejing, Xie. (1995). A global geochemical database for environmental and resource management. 19, UNESCO publishing, Paris.

Davenport, P.H., Christopher, T.K., Vardy, S., \& Nolan, L.W. (1993). Geochemical mapping in Newfoundland and Labrador: its role in establishing geochemical baselines for the measure of environmental change. Journal of Geochemical Exploration, Vol. 49, 177-200. 
DEFRA-EA. (2002a). Assessment of Risks to Human Health from Land Contamination: An Overview of the Development of the Soil Guideline Values and Related Research. R\&D Report CLR7. Department of the Environment, Food and Rural Affairs and the Environment Agency, Bristol, England.

DEFRA-EA. (2002b). Soil Guideline Values for Arsenic Contamination. Published March 2002. Report SGV1. Department of the Environment, Food and Rural Affairs and the Environment Agency, Bristol, England.

DEFRA-EA. (2002c). Soil Guideline Values for Cadmium Contamination. Published March 2002. Report SGV3. Department of the Environment, Food and Rural Affairs and the Environment Agency, Bristol, England.

DEFRA-EA. (2002d). Soil Guideline Values for Chromium Contamination. Published March 2002. Report SGV4. Department of the Environment, Food and Rural Affairs and the Environment Agency, Bristol, England.

DEFRA-EA. (2002e). Soil Guideline Values for compounds of inorganic Mercury Contamination. Published March 2002. Report SGV5. Department of the Environment, Food and Rural Affairs and the Environment Agency, Bristol, England.

DEFRA-EA. (2002f). Soil Guideline Values for Nickel Contamination. Published March 2002. Report SGV7. Department of the Environment, Food and Rural Affairs and the Environment Agency, Bristol, England.

DEFRA-EA. (2002g). Soil Guideline Values for Lead Contamination. Published March 2002. Report SGV10. Department of the Environment, Food and Rural Affairs and the Environment Agency, Bristol, England.

DEFRA-EA. (2002h). Soil Guideline Values for Selenium Contamination. Published March 2002. Report SGV9. Department of the Environment, Food and Rural Affairs and the Environment Agency, Bristol, England.

DETR. (2000). Contaminated Land: Implementation of Part IIa of the Environmental Protection Act. Department of Environment Transport and the Regions (now DEFRA). HMSO, London.

Diawara, M.M., Litt, J.S., Unis, D., Alfonso, N., Martinez, L., Crock, J.G., Smith, D.B., \& Carsella, J. (2006). Arsenic, cadmium, lead, and mercury in surface soils, Pueblo, Colorado: implications for population health risk. Environmental Geochemistry and Health, Vol. 28(4), 297-315.

Duzgoren-Aydin, N.S., Wong, C.S.C., Aydin, A., Song, Z., You, M., \& Li, X.D. (2006). Heavy metal contamination and distribution in the urban environment of Guangzhou, SE China. Environmental Geochemistry and Health, Vol. 28(4), 375-391.

Fersman, A.E. (1939). Geochemical and mineralogical methods of prospecting for useful minerals. in U.S. Geol. Surv. Circ. 127, 1952, 37pp. (US Geological Survey.)

Fordyce, F.M., Dochartaigh, B.É.Ó., Lister, T.L., Cooper, R., Kim, A.W., Harrison, I., Vane, C.H., \& Brown, S E. (2004). Clyde Tributaries: Report of Urban Stream Sediment and Surface Water Geochemistry for Glasgow. British Geological Survey, Keyworth, UK, Commissioned Report No. $\mathrm{CR} / 04 / 037$.

Fordyce, F.M., Brown, S.E., Ander, E.L., Rawlins, B.G., O’Donnell, K.E., Lister, T.R., Breward, N. \& Johnson, C.C. (2005). GSUE: Urban geochemical mapping in Great Britain. Geochemistry:

Exploration-Environment-Analysis, Vol. 5(4), 325-336. 
Fordyce, F.M., Nice, S.E., Lister, T.R., Ó Dochartaigh, B.É., Cooper, R., Allen, M., Ingham, M., Gowing, C., Vickers, B.P., \& Scheib, A. (In Prep) Urban Soil Geochemistry of Glasgow. British Geological Survey Internal Report, IR/04/100.

Grzebisz, W., Ciešla, L., Komisarek, J. \& Potarzycki, J. (2002). Geochemical assessment of heavy metals pollution of urban soils. Polish Journal of Environmental Studies, Vol. 11(5), 493-499.

Hawkes, H.E.\& Bloom, H. (1955). Heavy metals in stream sediment used as exploration guides. Mining Engineer, Vol. 8, 1121-1126.

Johnson, C C, Breward, N, Ander, E L, \& Ault, L. (2005). G-BASE: Baseline geochemical mapping of Great Britain and Northern Ireland. Geochemistry: Exploration-Environment-Analysis, Vol. 5(4), 347-357.

Jarva, J Conference presentation presented in this volume?

Johnson, C.C., Ander, E.L., Lister, T.R. \& Flight, D.M.A. (In Press). Data conditioning of environmental geochemical data: quality control procedures used in the British Geological Survey's Regional Geochemical Mapping Project. In: Environmental Geochemistry: Site Characterization, Data Analysis and Case Histories. De Vivo, B., Belkin, H.E. \& Lima, A. (Eds). Chapter X, XX-XX. Elsevier

Kelly, J., Thornton, I. \& Simpson, P.R. (1996). Urban Geochemistry: a study of the influence of anthropogenic activity on the heavy metal content of soils in traditionally industrial and nonindustrial areas of Britain. Applied Geochemistry, Vol. 11, 363-370.

Lee, C.S.-L., Xiangdong, L., Wenzhong, S. \& Cheung, S.C.-N. (2006). Metal contamination in urban, suburban, and country park soils of Hong Kong: A study based on GIS and multivariate statistics. Science of the Total Environment, Vol. 356, 45-61.

Ljung, K., Otabbong, E. \& Selinus, O. (2006). Natural and anthropogenic metal inputs to soils in urban Uppsala, Sweden. Environmental Geochemistry and Health, Vol. 28(4), 353-364.

Long, J F, Rain, D R, \& Ratcliffe, M R. (2001). Population Density vs. Urban Population: Comparative GIS Studies in China, India, and the United States. The International Union for the Scientific Study of Population (IUSSP) Conference. Session S68 on "Population Applications of Spatial Analysis Systems (SIS). Salvador, Brazil. 18 - 25 August 2001. available at: http://iussp.org/Brazil2001/s60/S68_01_Long.pdf.

Loredo, J., Ordonez, A., Charlesworth, S. \& De Miguel, E. (2003). Influence of industry on the geochemical urban environment of Mieres (Spain) and associated health risk. Environmental Geochemistry and Health, Vol. 25(3), 307-323.

Lovering, T.S, Huff, L.C. \& Almond, H. (1950). Dispersion of copper from the San Manuel copper deposit, Pinal County, Arizona. Economic Geology, Vol. 45, 493-514.

Madrid, L., Diaz-Barrientos, E., Ruiz-Cortés, E., Reinoso, R., Biasioli, M., Davidson, C.M., Duarte, A.C., Greman, H., Hossack, I., Hursthouse, A.S., Kralj, T., Ljung, K., Otabbong, E., Rodrigues, S., Urquhart, G.J. \& Ajmone-Marsan, F. (2006). Variability in concentrations of potentially toxic elements in urban parks from six European cities. Journal of Environmental Monitoring, Vol. 8, 1158-1165.

Manta, D.S., Angelone, M., Bellanca, A., Neri, R. \& Sprovieri, M. (2002). Heavy metals in urban soils: a case study from the city of Palermo (Sicily), Italy. The Science of the Total Environment, Vol. $300(1-3), 229-243$.

Markus, J.A. \& McBratney, A.B. (1996). An urban soil study: heavy metals in Glebe, Australia. Australian Journal of Soil Science, Vol. 34, 453-465. 
Matschullat, J, Ottenstein, R, \& Reimann, C. (2000). Geochemical background - can we calculate it? Environmental Geology, Vol. 39, 990-1000.

McAlister, J.J., Smith, B.J., Neto, J.B. \& Simpson, J.K. (2005). Geochemical distribution and bioavailability of heavy metals and oxalate in street sediments from Rio de Janeiro, Brazil: a preliminary investigation. Environmental Geochemistry and Health, Vol. 27, 429-441.

Mielke, H.W. (1994). Lead in New Orleans soils: new images of an urban environment. Environmental Geochemistry and Health, Vol. 16(3/4), 123-128.

Muchsin, M., Johnson, C.C., Crow, M.J., Djumsari, A. \& Sumartono. (1997). Atlas Geokimia Daerah Sumatera Bagian Selatan/ Geochemical Atlas of Southern Sumatra. Regional Geochemical Atlas Series of Indonesia. No. 2. (Directorate of Mineral Resources, Bandung, Indonesia and British Geological Survey, Keyworth, UK.)

\section{Nice et al? Reference to conference presentation if included in volume}

Norra, S., Lanka-Panditha, M., Kramar, U. \& Stüben, D. (2006). Mineralogical and geochemical patterns of urban surface soils, the example of Pforzheim, Germany. Applied Geochemistry, Vol. 21, 2064-2081.

Ordóñez, A., Loredo, J., De Miguel, E. \& Charlesworth, S. (2003). Distribution of heavy metals in the street dusts and soils of an industrial city in Northern Spain. Archives of Environmental Contamination and Toxicology, Vol. 44, 160-170.

Ottesen R... reference to conference presentation if included in volume

Ottesen, R.T. \& Langedal, M. (2001). Urban geochemistry in Trondheim, Norway. NGU-Bulletin, Vol. 438, 63-69.

Paterson, E., Sanka, M. \& Clark, L. (1996). Urban soils as pollutant sinks - a case study from Aberdeen, Scotland. Applied Geochemistry, Vol. 11(1-2), 129-131.

Plant, J.A. \& Moore, P.J. (1979). Geochemical mapping and interpretation in Britain. Philosophical Transactions of the Royal Society, Vol. B288, 95-112.

Plant, J A, Klaver, G., Locutura, J., Salminen, R., Vrana, K. \& Fordyce, F.M. (1997). The Forum of European Geological Surveys Geochemistry Task Group: geochemical inventory. Journal of Geochemical Exploration, Vol. 59, 123-146.

Ramsey, M.H., Thompson, M. \& Hale, M. (1992). Objective evaluation of precision requirements for geochemical analysis using robust analysis of variance. Journal of Geochemical Exploration 44, 23-36.

Rawlins, B.G. \& Brown, S.E. 2002. Assessing geostatistical methods for presenting urban soil geochemical data from Coventry. British Geological Survey, Keyworth, UK, Internal Report No. IR/03/012.

Rawlins, B.G., Lark, R.M, O'Donnell, K.E., Tye, A.M. \& Lister, T.R. (2005). The assessment of point and diffuse metal pollution of soils from an urban geochemical survey of Sheffield, England. Soil Use and Management, Vol. 21, 353-362.

Reimann, C., Äyräs, M., Chekushin, V., Bogatyrev, I., Boyd, R., de Cariat, P., Dutter, R., Finne, T.E., Halleraker, J.H., Jæger, Ø., Kahulina, G., Lehto, O., Nishavaara, H., Pavlov, V., Räisänen, M.L., Strand, T. \& Volden, T. (1998). Environmental Geochemical Atlas of the Central Barents Region. Geological Survey of Norway. ISBN 82-7385-176-1. 
Salminen, R. \& Tarvainen, T. (1997). The problem of defining geochemical baselines. A case study of selected elements and geological materials in Finland. Journal of Geochemical Exploration, Vol. $60,91-98$.

Salminen, R. \& Gregorauskiene, V. (2000). Considerations regarding the definition of a geochemical baseline of elements in the surficial materials in areas differing in basic geology. Applied Geochemistry, Vol. 15, 647-653.

Salminen, R., Tarvainen, T., Demetriades, A., Duris, M., Fordyce, F. M., Gregorauskiene, V., Kahelin, .H, Kivisilla, J., Klaver, .G, Klien, H., Larson, J. O., Lis, .J, Locutura, J., Marsina, K., Mjartanova, H., Mouvet, C., O'Connor, P., Odor, L., Ottonello, G., Paukola, T., Plant, J. A., Reimann, C., Schermann, O., Siewers, U., Steenfelt, A., Van der Sluys, J., de Vivo, B. \& Williams, L. (1998). FOREGS Geochemical Mapping Field Manual. Geological Survey of Finland, Guide 47.

Salminen, R., Batista, M.J., Bidovec, M., Demetriades, A., De Vivo, B., De Vos, W., Duris, M., Gilucis, A., Gregorauskiene, V., Halamic, J., Heitzmann, P., Lima, A., Jordan, G., Klaver, G., Klein, P., Lis, J., Locutura, J., Marsina, K., Mazrek, U.A., O'Connor, P.J., Olsson, S.Å., Ottesen, R.T., Petersell, V., Plant, J.A., Reeder, S., Salpeteur, I., Sandström, H., Siewers, U., Steenfelt, A. \& Tarvainen, T. (2005). Geochemical Atlas of Europe. Part 1 - Background Information, Methodology and Maps. Geochemical Atlas of Europe. (Geological Survey of Finland.) ISBN 951-690-921-3

Salonen, V.-P. \& Korkka-Niemi, K. (2007). Influence of parent sediments on the concentration of heavy metals in urban and suburban soils in Turku, Finland. Applied Geochemistry, Vol. 22, 906918.

Sewell, R.J. (1999). Geochemical Atlas of Hong Kong. Geotechnical Office, Civil Engineering Department, Hong Kong. ISBN 962-02-0274-0

Sinclair, A.J. (1976). Applications of probability graphs in mineral exploration. The Association of Exploration Geochemists. Spec. Vol. No. 4.

Tarvainan, T, Eklund, M, Haavisto_Hyvärinen, M, Hatakka, T, Jarva, J, Karttunen, V, Kuusisto, E, Ojalainen, J. \& Teräsvuori, E. (2006). Summary: Geochemical baselines around the Helsinki metropolitan area. Geological Survey of Finland.

Tarvainan, T. et al., 2006. Summary: Geochemical baselines around the Helsinki metropolitan area, Geological Survey of Finland, Espoo. Only use if J Java ref. Not published

Thornton, I. (1991). Metal contamination of soils in urban areas. In: Bullock, P. \& Gregory, P.J. (Eds), Soils in the Urban Environment. British Society of Soil Science. Chapter 4, 47 - 75. Blackwell Scientific Publications, Oxford

Thornton, I. \& Webb, J.S. (1979). Geochemistry and health in the United Kingdom. Philosophical Transactions of the Royal Society, Vol. B288, 151-168.

Thornton, I, Watt, J M, Davies, D J A, Hunt, A, Cotter-Howells, J, \& Johnson, D L. (1994). Lead contamination of UK dusts and soils and implications for childhood exposure: an overview of the work of the Environmental Geochemistry Research Group, Imperial College, London, England 1981-1992. Environmental Geochemistry and Health, Vol. 16, 113 - 122.

Tidball, R R, Erdman, J A, \& Ebens, R J. (1974). Geochemical baselines for sagebrush and soil, Powder River Basin, Montama Wyoming. US Geological Survey Open-file Report, Vol. 74-250, 613.

Tijhuis, L., Brattli, B. \& Sæther, O.M. (2002). A geochemical survey of topsoil in the city of Oslo, Norway. Environmental Geochemistry and Health, Vol. 24, 67-94. 
Tye, A.M., Hodgkinson, E.S. \& Rawlins, B.G. (2006). Microscopic and chemical studies of metal particles in tree bark and attic dust: evidence for historical atmospheric smelter emissions, Humberside, UK. Journal of Environmental Monitoring, Vol. 8, 904-912.

UN (2006). World Urbanization Prospects. The 2005 Revision. Department of Economic and Social Affairs, Population Division. Document reference ESA/P/WP/200. New York. October 2006

US Census Bureau (1995). Urban and Rural Definitions. A note released October 1995. US Census Bureau, Washington, USA. Available at: http://www.census.gov/population/censusdata/urdef.txt

Vrana, K., Rapant, S., Bodiš, D., Marina, K., Lexa, J., Pramuka, S., Mankovská, B., Curlík, J., Šefcík, P., Vojtaš, J., Daniel, J. \& Lucivianský L. (1997). Geochemical Atlas of Slovak Republic at a scale 1:1,000,000. Journal of Geochemical Exploration, 60, 1, 7-37.

Wang, X.S., Qin, Y. \& Sang, S.X. (2005). Accumulation and sources of heavy metals in urban topsoils: a case study from the city of Xuzhou, China. Environmental Geology, Vol. 48(1), 101-107.

Webb, J S. 1964. Geochemistry and life. New Scientist, Vol. 406, 504-507.

Wood, M.D., Copplestone, D. \& Crook, P. (2007). UK Soil and Herbage Pollutant Survey. UKSHS Report No. 2. Chemical and radiometric sample collection methods. Environment Agency (England and Wales). ISBN: 978-1-84432-767-6.

Wong, C.S.C., Li, X.D. \& Thornton, I. (2006). Urban environmental geochemistry of trace metals. Environmental Pollution, Vol. 142, 1-16.

Xinmin, Z., Kunli, L., Xinzhang, S., Jian'an, T. \& Yilun, L. (2006). Mercury in the topsoil and dust of Beijing City. Science of The Total Environment, Vol. 368(2-3), 713-722.

Yin, X., Liu, X., Sun, L., Zhu, R., Xie, Z. \& Wang, Y. (2006). A 1500-year record of lead, copper, arsenic, cadmium, zinc level in Antarctic seal hairs and sediments. Science of the Total Environment, Vol. 371, 252-257.

Yongming, H., Peixuan, D., Junji, C. \& Posmentier, E.S. (2006). Multivariate analysis of heavy metal contamination in urban dusts of Xi'an, Central China. Science of The Total Environment, Vol. 355(1-3), 176-186. 
Figure 1: Figure showing a regional geochemical map for Scotland based on samples collected in the 1970s (from the G-BASE project)

$<<<<<$ IN COLOUR $>>>>$

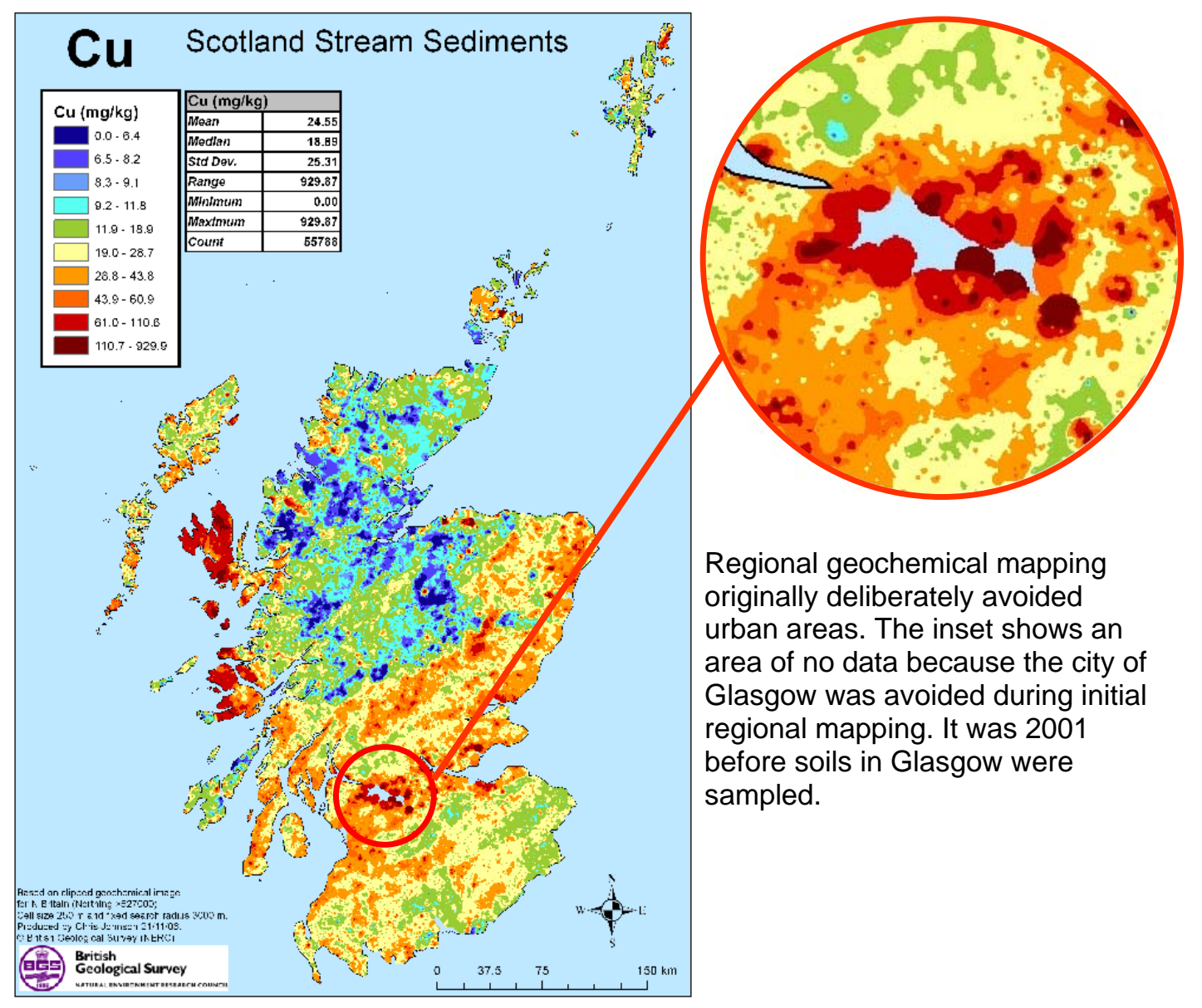


Figure 2: A figure that shows how the G-BASE project defines areas for urban geochemical mapping

$<<<<$ can be done in Black \& White $>>>>$

1:50,000 scale Ordnance Survey topographic maps are used to define urban areas. An urban boundary is drawn around the parts of the map showing a predominantly built-up ornament. (Background grid is $1 \mathrm{~km}$ intervals on reduced coloured map reproduced here in greyscale).

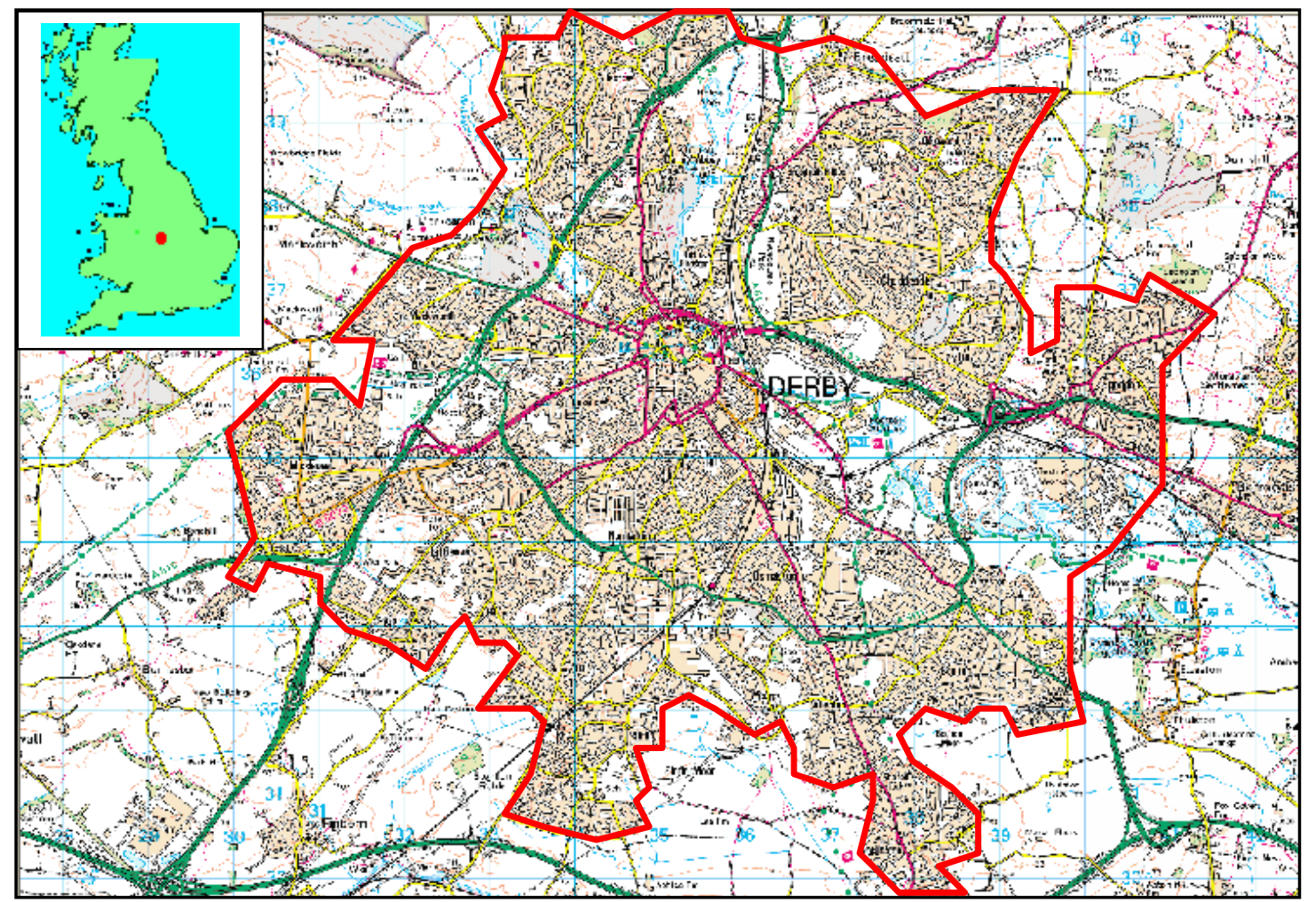

This map is based upon Ordnance Survey topographic material. (C) Crown Copyright. All rights reserved. OS licence No. 100017897/2007 
$<<<$ Figures 3 \& 4 can be presented in Black \& White $>>>>$

Figure 3: Classified symbol plot for lead in surface soils from Derby (UK)

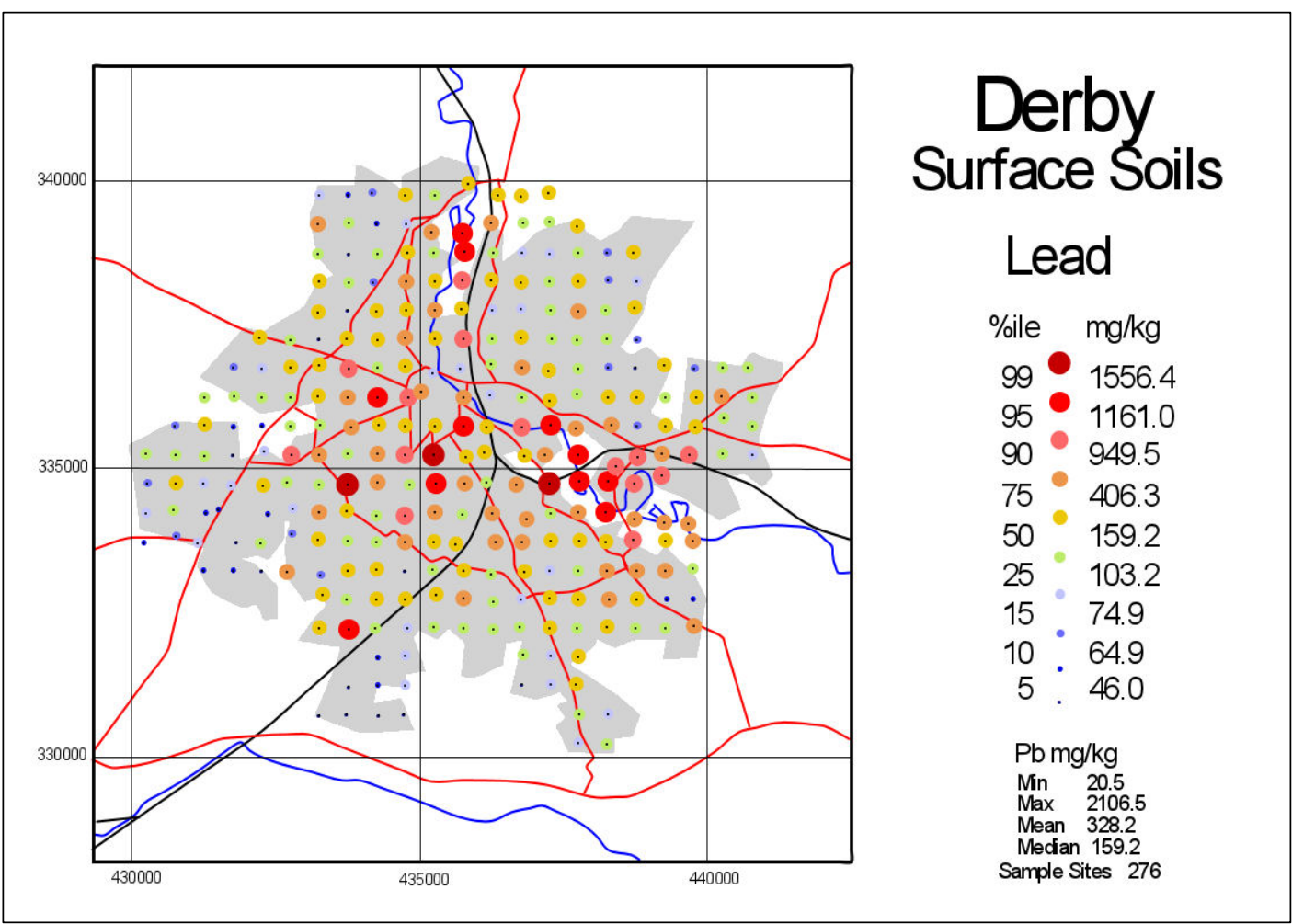

Figure 4: Example of a box and whisker plot. Mean is shown by square symbol, $25^{\text {th }}$ (Q1) and $75^{\text {th }}(\mathrm{Q} 3)$ percentiles define bottom and top of box, median $\left(50^{\text {th }}\right.$ percentile) is the line across the box. Lower whisker extends to (Q1 - 1.5(Q1-Q3)) and upper whisker extends to (Q3 + 1.5(Q1-Q3)).

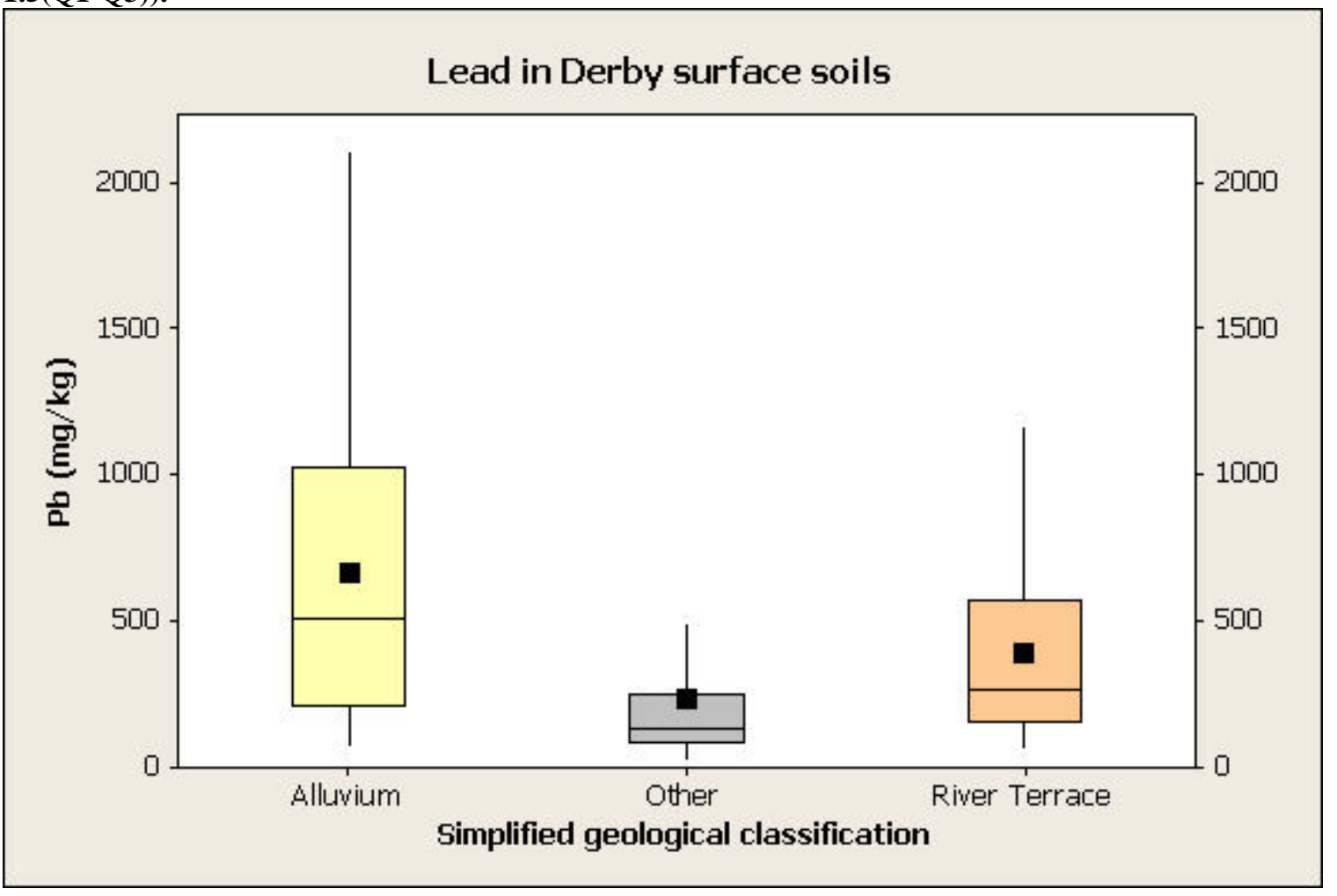


Figure 5: Lead in topsoils from Derby, UK. An example of a cumulative probability plot

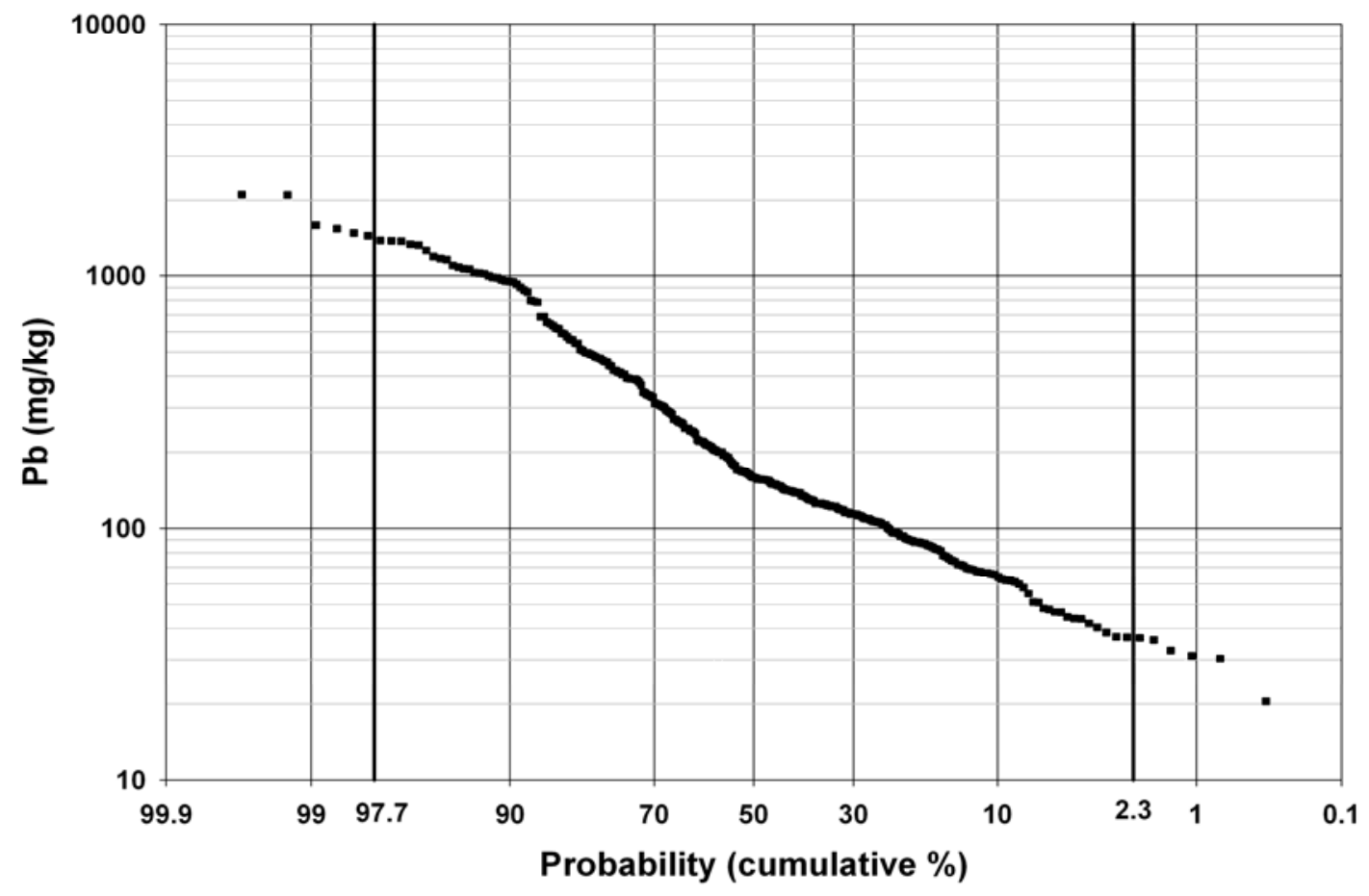




\begin{tabular}{|c|c|c|c|c|c|}
\hline Reference & Location & Aims/Objective & $\begin{array}{l}\text { Sample } \\
\text { Media }\end{array}$ & Sampling Method & Analytical Method \\
\hline $\begin{array}{l}\text { Ahmed et al. } \\
\text { (2007) }\end{array}$ & $\begin{array}{l}\text { Dhaka, } \\
\text { Bangladesh }\end{array}$ & $\begin{array}{l}\text { Assess present environmental conditions and describe the possible } \\
\text { sources of trace metals, esp. PB \& Zn, in street dusts of Dhaka }\end{array}$ & $\begin{array}{l}\mathrm{RDS} \\
(<1 \mathrm{~mm})(59)\end{array}$ & $\begin{array}{l}\text { Collected from pavement edges with } \\
\text { plastic pan \& brush }\end{array}$ & XRFS \& NAA \\
\hline $\begin{array}{l}\text { Al-Khashman } \\
(2007)\end{array}$ & $\begin{array}{l}\text { Amman, } \\
\text { Jordan }\end{array}$ & $\begin{array}{l}\text { Define essential characteristics of metal levels and sources of metal } \\
\text { pollution in street dust samples }\end{array}$ & $\begin{array}{l}\text { RDS } \\
<2 \mathrm{~mm}(120)\end{array}$ & $\begin{array}{l}\text { Collected from pavement edges } \\
\text { either side of road with pan \& brush. } \\
2 \text { sub-samples composited }\end{array}$ & $\begin{array}{l}\text { conc. } \mathrm{HNO}_{3} \text { extraction followed by } \\
\text { determination of } \mathrm{Fe}, \mathrm{Cu}, \mathrm{Cd}, \mathrm{Pb}, \mathrm{Zn} \\
\& \mathrm{Ni} \text {. + organic matter }\end{array}$ \\
\hline $\begin{array}{l}\text { Barraclough } \\
(2007)\end{array}$ & Urban sites, UK & Baseline against which intensive local surveys can be assessed & $\begin{array}{l}\mathrm{S}(0-5)<? \mathrm{~mm} \\
(78)\end{array}$ & $\begin{array}{l}\text { Sampled with Eijkelkamp coring kit. } \\
3 \text { sub-samples composited from } \\
20 \mathrm{~m} \text { square }\end{array}$ & $\begin{array}{l}\text { AqRE followed by ICP-MS /OES \& } \\
\mathrm{CV}-\mathrm{AAS} \text { for } \mathrm{As}, \mathrm{Cd}, \mathrm{Cr}, \mathrm{Cu}, \mathrm{Pb}, \mathrm{Mn} \text {, } \\
\mathrm{Hg}, \mathrm{Ni}, \mathrm{Pt}, \mathrm{Sn}, \mathrm{Ti}, \mathrm{V} \& \mathrm{Zn},+\mathrm{pH} \& \\
\text { LOI, +range of organic } \\
\text { determinations }\end{array}$ \\
\hline $\begin{array}{l}\text { Biasioli et al. } \\
2006\end{array}$ & Torino, Italy & $\begin{array}{l}\text { To evaluate the influence of a large city on its soils and on the } \\
\text { surrounding ones with reference to some soil properties and heavy } \\
\text { metal content }\end{array}$ & $\begin{array}{l}\mathrm{S}(0- \\
20)<2 \mathrm{~mm}(70)\end{array}$ & $\begin{array}{l}\text { From parks and roadside. } \\
\text { Composite of } 4 \text { sub-samples taken } \\
\text { at corners of } 1 \mathrm{~m} \text { square with spade }\end{array}$ & $\begin{array}{l}\text { AqRE followed by AAS. CEC, pH } \\
\text { and organic } C \text { also determined }\end{array}$ \\
\hline $\begin{array}{l}\text { Birke \& Rauch } \\
(2000)\end{array}$ & $\begin{array}{l}\text { Berlin, } \\
\text { Germany }\end{array}$ & $\begin{array}{l}\text { Development of a scientific basis for recognition and evaluation of } \\
\text { polluted areas a priority project of Fedral Government }\end{array}$ & $\begin{array}{l}\mathrm{S}(0-20)<2 \mathrm{~mm} \\
(4000)\end{array}$ & $\begin{array}{l}\text { Densely populated and industrial } \\
\text { areas sampled at a density of } 40 \\
\text { samples per } \mathrm{km}^{2} \text {. }\end{array}$ & $\begin{array}{l}41 \text { trace \& } 11 \text { major elements plus } \\
\text { pH \& TOC. Mainly by XRFS }\end{array}$ \\
\hline $\begin{array}{l}\text { Bityukova et } \\
\text { al. (2000) }\end{array}$ & Tallinn, Estonia & $\begin{array}{l}\text { Important contribution to the characterisation of the state of the } \\
\text { environment }\end{array}$ & $\begin{array}{l}\mathrm{S}(0-10)<1 \mathrm{~mm} \\
(532)\end{array}$ & $\begin{array}{l}\text { Sampling on } 2 \mathrm{~km} \text { grid. Each sample } \\
\text { collected from a square of } 15 \times 15 \mathrm{~cm}\end{array}$ & $\begin{array}{l}\text { XRFS (13 - } 21 \text { elements); } 198 \mathrm{~S} \\
\text { from Tallin also determined by OES } \\
\text { (22 elements) }\end{array}$ \\
\hline $\begin{array}{l}\text { Carrez et al. } \\
(2006)\end{array}$ & $\begin{array}{l}\text { Manchester, } \\
\text { UK }\end{array}$ & $\begin{array}{l}\text { Determine spatial variability in road deposited sediment across the } \\
\text { city centre focusing on the coarser fraction which is likely to impact } \\
\text { surface water quality }\end{array}$ & $\begin{array}{l}\text { RDS }<2 \mathrm{~mm}(100) \\
\text { also }<63 \mu \mathrm{m} \\
\text { fraction studied }\end{array}$ & $\begin{array}{l}4 \text { samples per } \mathrm{km}^{2} \text { over } 25 \mathrm{~km}^{2} \\
\text { area. Used dust pan \& brush. }\end{array}$ & $\begin{array}{l}\text { Digested in } 0.5 \mathrm{M} \mathrm{HCl} \text { followed by } \\
\text { AAS determination of } \mathrm{Cu}, \mathrm{Fe}, \mathrm{Mn} \text {, } \\
\mathrm{Pb} \& \mathrm{Zn}+\text { LOI. }\end{array}$ \\
\hline $\begin{array}{l}\text { Diawara et al. } \\
(2006)\end{array}$ & $\begin{array}{l}\text { Pueblo, } \\
\text { Colorado, USA }\end{array}$ & Address concerns about environmental contamination & $\begin{array}{l}S(0-5)<2 \mathrm{~mm} \\
(66)\end{array}$ & $\begin{array}{l}\text { Four transects, } 3 \mathrm{~km} \text { apart, every } 2 \\
\mathrm{~km} \text { along transect giving } 33 \\
\text { sampling sites. Two } 25 \times 25 \mathrm{~cm} \\
\text { collection areas }\end{array}$ & $\begin{array}{l}4 \text { acid extraction, } \mathrm{Cd} \& \mathrm{~Pb} \text { by ICP- } \\
\text { MS, As and } \mathrm{Hg} \text { by AAS. }\end{array}$ \\
\hline $\begin{array}{l}\text { Duzgoren- } \\
\text { Aydin et al. } \\
\text { (2006) }\end{array}$ & $\begin{array}{l}\text { Guangzhou, } \\
\text { China }\end{array}$ & $\begin{array}{l}\text { Determine the distribution and level of heavy metal contamination in } \\
\text { different urban settings to identify potential sources and to provide } \\
\text { guidance for planning remedial actions }\end{array}$ & $\begin{array}{l}\text { Road dust (15); } \\
\text { tunnel ceiling } \\
\text { dust }(2) ; \& \\
\text { gulley seds (13) } \\
\text { (all <2mm) }\end{array}$ & $\begin{array}{l}30 \text { composited samples from } 14 \\
\text { sites. Road and tunnel dust collected } \\
\text { with plastic dustpan \& brush. Gulley } \\
\text { sediments with plastic scoop. }\end{array}$ & $\begin{array}{l}\mathrm{HF} / \mathrm{HNO}_{3} \text { digestion followed by ICP- } \\
\mathrm{MS} \text { (18 elements) }\end{array}$ \\
\hline $\begin{array}{l}\text { Fordyce et al. } \\
\text { (2005) (use } \\
\text { Nice reference } \\
\text { if published in } \\
\text { this volume) }\end{array}$ & $\begin{array}{l}21 \text { cites, Great } \\
\text { Britain }\end{array}$ & $\begin{array}{l}\text { Provide overview of the urban geochemical signature and because } \\
\text { they are collected as part of natinal baseline mapping soils can be } \\
\text { assessed for extent of urban contamination. Direct relevance to UK } \\
\text { land use planning, urban regeneration and contaminated land } \\
\text { legislative regimes }\end{array}$ & $\begin{array}{l}\mathrm{S}(5-20)<2 \mathrm{~mm} \\
\mathrm{~S}(35-50)<2 \mathrm{~mm} \\
\text { (pre-2000 used } \\
<150 \mu \mathrm{m} \text { for } \\
\text { deep soil)) } \\
(>17000)\end{array}$ & $\begin{array}{l}\text { Soil samples collected with } 1 \mathrm{~m} \\
\text { stainless steel Dutch auger. Each } \\
\text { sample a composite of } 5 \text { sub- } \\
\text { samples collected at corners \& } \\
\text { centre of } 20 \mathrm{~m} \text { square. Density of } 4 \\
\text { samples per } \mathrm{km}^{2} \text {. }\end{array}$ & $\begin{array}{l}46 \text { elements by XRFS (earliest } \\
\text { urban sampling only } 18 \text { elements) }\end{array}$ \\
\hline $\begin{array}{l}\text { Grzebisz et al. } \\
(2002)\end{array}$ & $\begin{array}{l}\text { Poznan, } \\
\text { Poland }\end{array}$ & $\begin{array}{l}\text { Identify heavy metals with dangerous environmental load and to } \\
\text { define areas of their environmental impact. }\end{array}$ & $\begin{array}{l}\mathrm{S}(0-20)<? \mathrm{~mm} \\
(350)\end{array}$ & $\begin{array}{l}350 \text { randomly chosen soil sites over } \\
261 \mathrm{~km}^{2} \text {. }\end{array}$ & $\begin{array}{l}\text { AqRE followed by AAS for } \mathrm{Cd}, \mathrm{Pb} \\
\mathrm{Cu} \& \mathrm{Zn}\end{array}$ \\
\hline $\begin{array}{l}\text { Kelly \& } \\
\text { Thornton } \\
\text { (1996) }\end{array}$ & $\begin{array}{l}\text { Wolverhampton } \\
\text { \& London, } \\
\text { England }\end{array}$ & $\begin{array}{l}\text { Assess the influence of urbanisation and industrial activity in Britain } \\
\text { on the heavy metal content of topsoils }\end{array}$ & $\begin{array}{l}S(0-15)<2 \mathrm{~mm} \\
(509)\end{array}$ & $\begin{array}{l}4 \text { samples per } \mathrm{km}^{2} \text { composite of } 9 \\
\text { sub-samples from a } 4 \mathrm{~m}^{2} \text { grid }\end{array}$ & $\begin{array}{l}\mathrm{HNO}_{3} / \mathrm{HCLO}_{4} / \mathrm{HCl} \text { extraction } \\
\text { followed by ICP-AES ( } 25 \text { elements). }\end{array}$ \\
\hline
\end{tabular}




\begin{tabular}{|c|c|c|c|c|c|}
\hline $\begin{array}{l}\text { Lee et al. } \\
\text { (2006) }\end{array}$ & Hong Kong & $\begin{array}{l}\text { To assess and compare metal contamination in soils of urban, sub- } \\
\text { urban, and country park areas of Hong Kong. To evaluate the } \\
\text { relationship between heavy metals and their possible sources using } \\
\text { GIS. To identify anthropogenic sources of PB using isotopic } \\
\text { composition analysis. }\end{array}$ & $\begin{array}{l}\mathrm{S}(0-10)<2 \mathrm{~mm} \\
(298)\end{array}$ & $\begin{array}{l}80 \mathrm{~km}^{2} \text { cells. } 5 \text { samples per cell } \\
\text { (urban), } 2 \text { per cell (sub-urban). } 9 \\
\text { composited sub-samples using } \\
\text { stainless steel hand auger on } 2 \times 2 \mathrm{~m} \\
\text { grid }\end{array}$ & $\begin{array}{l}\text { AqRE extraction followed by ICP- } \\
\text { AES } 12 \text { elements) and } \mathrm{Hg} \text { by } \\
\text { flameless AAS. } \mathrm{Pb} \text { isotopes using } \\
\text { ICP-MS. }\end{array}$ \\
\hline $\begin{array}{l}\text { Ljung et al. } \\
\text { (2006) }\end{array}$ & $\begin{array}{l}\text { Uppsala, } \\
\text { Sweden }\end{array}$ & $\begin{array}{l}\text { Attempts to make a distinction between soil metal contents derived } \\
\text { from natural sources and metal contents that are a result of } \\
\text { anthropogenic activities }\end{array}$ & $\begin{array}{l}\mathrm{S}(0-5)<2 \mathrm{~mm} \\
\mathrm{~S}(5-10)<2 \mathrm{~mm} \\
\mathrm{~S} 10-20)<2 \mathrm{~mm}\end{array}$ & $\begin{array}{l}5 \text { sub-samples within } 1 \mathrm{~m} 2 \text { collected } \\
\text { using stainless steel auger. } 75 \text { soils } \\
\text { from } 25 \text { sites }\end{array}$ & $\begin{array}{l}\text { AqRE and analysis of } \mathrm{Al}, \mathrm{As}, \mathrm{Cd}, \\
\mathrm{Cr}, \mathrm{Cu}, \mathrm{Fe}, \mathrm{Hg}, \mathrm{Mn}, \mathrm{Ni}, \mathrm{Pb}, \mathrm{W} \& \mathrm{Zn} \\
\text { by ICP-AES and/or ICP-MS,+ LOI \& } \\
\text { pH. }\end{array}$ \\
\hline $\begin{array}{l}\text { Loredo et al. } \\
\text { (2003) }\end{array}$ & Mieres, Spain & $\begin{array}{l}\text { Study of soils and street dust in historical industrial city ( } \mathrm{Hg} \text { mining } \\
\text { and metallurgical activities). }\end{array}$ & $\begin{array}{l}\mathrm{S}(0-20)<2 \mathrm{~mm} \\
(18) \text { Street } \\
\text { dust<2mm (48) }\end{array}$ & $\begin{array}{l}3 \mathrm{~km}^{2} \text { area. Soils composed of } 5 \\
\text { bulked sub-samples collected on } 2 \mathrm{~m} \\
\text { cross pattern. Stainless steel } \\
\text { "equipment" used to dig holes and } \\
\text { sampling with plastic utensils. }\end{array}$ & $\begin{array}{l}\text { AqRE followed by ICP-MS ( } 27 \\
\text { elements) and } \mathrm{Hg} \text { by flameless } \\
\text { AAS }\end{array}$ \\
\hline $\begin{array}{l}\text { Madrid et al. } \\
\text { (2006) }\end{array}$ & $\begin{array}{l}\text { Aveiro, } \\
\text { Glasgow; } \\
\text { Ljubljana, } \\
\text { Seville, Torino, } \\
\text { \& Uppsala }\end{array}$ & $\begin{array}{l}\text { Soil quality is currently a topic of considerable importance in Europe, } \\
\text { as consultation progresses on development of a Thematic strategy } \\
\text { on the Protection of Soil under the 6th Environmental Action } \\
\text { Programme of the European Community. The URBSOIL project is } \\
\text { aimed at assessing the role of urban soils as a source and sink for } \\
\text { pollutants. }\end{array}$ & $\begin{array}{l}\mathrm{S}(0-10)<2 \mathrm{~mm} \\
(160) \\
\mathrm{S}(10-20)<2 \mathrm{~mm}\end{array}$ & $\begin{array}{l}\text { Each city had sampling grid of at } \\
\text { least } 25 \text { points }(50 \times 50 \mathrm{~m} \text { ) apart. } \\
\text { Samples collected with a trowel or } \\
\text { plastic lined corer }\end{array}$ & $\begin{array}{l}\text { AqRE followed by determination of } \\
\mathrm{Cu}, \mathrm{Cr}, \mathrm{Ni}, \mathrm{Pb}, \mathrm{Zn} \text { by ICP-MS or - } \\
\mathrm{AES}+\mathrm{pH} \& \mathrm{LOI}\end{array}$ \\
\hline $\begin{array}{l}\text { Manta et al. } \\
(2002)\end{array}$ & Palermo, Italy & $\begin{array}{l}\text { Assess the distribution of heavy metals in the urban environment, } \\
\text { discriminate natural and anthropogenic contributions, and identify } \\
\text { possible sources of pollution }\end{array}$ & $\begin{array}{l}S(0-10)<2 \mathrm{~mm} \\
(70)\end{array}$ & $\begin{array}{l}\text { Topsoils from green areas of } \\
\text { Palermo. } 3 \text { sub-samples from } 20 x \\
20 \mathrm{~cm} \text { area }\end{array}$ & $\begin{array}{l}\text { XRFS (major elements) }+\mathrm{pH}, \mathrm{LOI} \\
\text { and CEC. Also AqRE followed by } \\
\text { AAS/ICP-MS for trace elements. Hg } \\
\text { by direct mercury analyser }\end{array}$ \\
\hline $\begin{array}{l}\text { Markus \& } \\
\text { McBratney } \\
\text { (1996) }\end{array}$ & $\begin{array}{l}\text { Glebe, Sydney, } \\
\text { Australia }\end{array}$ & $\begin{array}{l}\text { Primary aim was to determine the total concentration and spatial } \\
\text { distribution of } \mathrm{Pb}, \mathrm{Zn}, \mathrm{Cu} \text { and } \mathrm{Cd} \text { in the topsoil of Glebe and } \\
\text { concentrations were compared with environmental investigation } \\
\text { limits }\end{array}$ & $\begin{array}{l}\mathrm{S}(0-10)<2 \mathrm{~mm} \\
(219)\end{array}$ & $\begin{array}{l}\text { One site per } 100 \times 100 \mathrm{~m} \text { cell taken } \\
\text { at random. Two samples from each } \\
\text { site taken } 1 \mathrm{~m} \text { apart to determine } \\
\text { spatial variability. } 10 \mathrm{~cm} \text { auger used }\end{array}$ & $\begin{array}{l}\text { AqRE followed by AAS } \\
\text { determination of } \mathrm{Pb}, \mathrm{Zn}, \mathrm{Cu} \text { and } \mathrm{Cd} \text {. } \\
\text { pH also determined }\end{array}$ \\
\hline $\begin{array}{l}\text { McAlister et al. } \\
(2005)\end{array}$ & $\begin{array}{l}\text { Rio Janeiro, } \\
\text { Brazil }\end{array}$ & $\begin{array}{l}\text { To assess the nature and extent of the health risks relating to } \\
\text { "heavy metal", sewage and vehicle pollution. }\end{array}$ & $\mathrm{RDS}<63 \mu \mathrm{m}$ & $\begin{array}{l}\text { Sweeping large area of road from } \\
\text { pavement towards centre of road }\end{array}$ & $\begin{array}{l}\text { Selective extraction procedure } \\
\text { followed by } A A S \text { for heavy metals. } \\
\text { Oxalate }\left(\mathrm{C}_{2} \mathrm{O}_{4}^{-}\right) \text {determined by ion } \\
\text { chromatograph. } \mathrm{pH}+\text { organic } \mathrm{C} \\
\text { determined }\end{array}$ \\
\hline Mielke (1994) & $\begin{array}{l}\text { New Orleans, } \\
\text { USA }\end{array}$ & Map lead in the soils of New Orleans & $\begin{array}{l}\mathrm{S}(0-2.5) \\
\text { (surface } \\
\text { scrape). USGS } \\
\# 10 \text { sieve } \\
(<2 \mathrm{~mm})(3704)\end{array}$ & $\begin{array}{l}\text { Roadside soils (within } 1 \mathrm{~m} \text { of street), } \\
\text { houseside ( } 1 \mathrm{~m} \text { of house matched } \\
\text { with roadside sample) and open } \\
\text { spaces away from streets and } \\
\text { houses }\end{array}$ & $\begin{array}{l}\text { Digestion with } 1 \mathrm{M} \mathrm{HNO} \text { followed by } \\
\text { determination of } \mathrm{Pb} \text { by AAS }\end{array}$ \\
\hline $\begin{array}{l}\text { Norra et al. } \\
(2006)\end{array}$ & $\begin{array}{l}\text { Pforzheim, } \\
\text { Germany }\end{array}$ & $\begin{array}{l}\text { Evaluate the application of mineralogical investigations to urban } \\
\text { geochemical soil surveys. To investigate the impact of urbanization } \\
\text { on the mineralogical composition of soil. }\end{array}$ & $\begin{array}{l}\mathrm{S}(0-5)<2 \mathrm{~mm} \\
(58)\end{array}$ & $\begin{array}{l}\text { Composite of } 3 \text { samples taken } 1 \mathrm{~m} \\
\text { sided triangle }\end{array}$ & $\begin{array}{l}21 \text { elements by XRFS plus } \mathrm{pH} \text { and } \\
\text { total C }\end{array}$ \\
\hline $\begin{array}{l}\text { Ordóñez et al. } \\
\text { (2003) }\end{array}$ & Avilés, Spain & $\begin{array}{l}\text { Attempts to differentiate between metals produced naturally and } \\
\text { those produced as a result of industry and those distributed in } \\
\text { relation to traffic movements. }\end{array}$ & $\begin{array}{l}\mathrm{S}(0-15)<2 \mathrm{~mm} \\
(40) \text { Street } \\
\text { dust<2 } \mathrm{mm} \\
(112)\end{array}$ & $\begin{array}{l}5 \text { soil subsamples collected on } 10 \mathrm{~m} \\
\text { cross pattern using plastic trowel. } \\
\text { Dust collected with plastic utensils }\end{array}$ & $\begin{array}{l}\text { AqRE followed by ICP-MS ( } 27 \\
\text { elements) and Hg by flameless } \\
\text { AAS }\end{array}$ \\
\hline
\end{tabular}




\begin{tabular}{|c|c|c|c|c|c|}
\hline $\begin{array}{l}\text { Ottesen \& } \\
\text { Langedall } \\
\text { (2001) }\end{array}$ & $\begin{array}{l}\text { Trondheim, } \\
\text { Norway }\end{array}$ & $\begin{array}{l}\text { To assess whether emissions have elevated certain elements and } \\
\text { provide a database for environmental risk evaluation. Also provides } \\
\text { background for further community planning }\end{array}$ & $\begin{array}{l}\mathrm{S}(0-2)<2 \mathrm{~mm} \\
(314)\end{array}$ & $\begin{array}{l}\text { Soils collected at density of } 4.5 \\
\text { samples per } \mathrm{km}^{2} \text {. }\end{array}$ & $\begin{array}{l}\text { AqRE then determination } 31 \\
\text { elements by ICP-AES plus some by } \\
\text { AAS. + LOI }\end{array}$ \\
\hline $\begin{array}{l}\text { Paterson et al. } \\
\text { (1996) }\end{array}$ & $\begin{array}{l}\text { Aberdeen, } \\
\text { Scotland }\end{array}$ & $\begin{array}{l}\text { Establish a baseline in order to assess the extent urban soils have } \\
\text { been altered by anthropogenic influences }\end{array}$ & $\begin{array}{l}\mathrm{S}(0-10)<2 \mathrm{~mm} \\
(50)\end{array}$ & $\begin{array}{l}\text { Roadside locations at least } 1 \mathrm{~m} \text { from } \\
\text { road. } 10 \text { composite samples } \\
\text { collected from within } 2 \times 5 \mathrm{~m} \\
\text { rectangle }\end{array}$ & $\begin{array}{l}\text { AqRE followed by ICP-AES for } 19 \\
\text { elements }+\mathrm{pH} \text {. }\end{array}$ \\
\hline $\begin{array}{l}\text { Salonen \& } \\
\text { Korkka-Niemi } \\
\text { (2007) }\end{array}$ & Turku, Finland & $\begin{array}{l}\text { To examine the influence of parent sediment material on soil } \\
\text { geochemistry and to locate possible pollution sources }\end{array}$ & $\begin{array}{l}S(0-5)<60 \mu \\
(100) \\
S(50-100)<60 \mu \\
(50)\end{array}$ & $\begin{array}{l}\text { Different glacial parent materials } \\
\text { sampled. Dug with spade } 4 \\
\text { composite samples from } 25 \mathrm{~m}^{2} \text { grid. }\end{array}$ & $\begin{array}{l}21 \text { elements. Conc. } \mathrm{HNO}_{3} \\
\text { extraction. ICP-AES, AAS + LOI }\end{array}$ \\
\hline $\begin{array}{l}\text { Tarvainen et } \\
\text { al. (2006) }\end{array}$ & $\begin{array}{l}\text { Helsinki, } \\
\text { Finland }\end{array}$ & $\begin{array}{l}\text { To provide regional environmental authorities with information on } \\
\text { geological and diffuse anthropogenic baselines of different elements. }\end{array}$ & $\begin{array}{l}\text { S (pit } \\
\text { profileSoil) } \\
<2 \mathrm{~mm}(300)\end{array}$ & $\begin{array}{l}300 \text { pits from around the Helsinki } \\
\text { area to represent most common } \\
\text { mineral soil types }\end{array}$ & $\begin{array}{l}\text { AqRE for mineral soils, conc. } \mathrm{HNO}_{3} \\
\text { for humus. } 30+\text { elements + LOI and } \\
\text { pH mainly ICP-MS/AES }\end{array}$ \\
\hline $\begin{array}{l}\text { Tijhuis et al. } \\
\text { (2002) }\end{array}$ & Oslo, Norway & $\begin{array}{l}\text { Risks from contaminated land and groundwater pollution are high } \\
\text { and have a high priority in Norway. }\end{array}$ & $\begin{array}{l}\mathrm{S}(2-3)<2 \mathrm{~mm} \\
(c .300)\end{array}$ & $\begin{array}{l}\text { Surface soils at one sample per } \mathrm{km}^{2} \text {. } \\
20 \times 10 \mathrm{~cm} \text { cut with spade and } \\
\text { sample collected with knife }\end{array}$ & $\begin{array}{l}\text { 7M } \mathrm{HNO}_{3} \text { dissolution followed by } \\
29 \text { elements (ICP-AES); Hg by CV- } \\
\text { AAS; As \& Cd by GF-AAS. }\end{array}$ \\
\hline $\begin{array}{l}\text { Wang et al. } \\
\text { (2005) }\end{array}$ & Xuzhou, China & $\begin{array}{l}\text { Assess the distribution of heavy metals, discriminate } \\
\text { natural/anthropogenic contributions, and identify possible sources of } \\
\text { pollution }\end{array}$ & $\begin{array}{l}\mathrm{S}(0-10)<2 \mathrm{~mm} \\
(21)\end{array}$ & $\begin{array}{l}\text { A composite of } 3 \text { sub-samples over } \\
20 \times 20 \mathrm{~cm} \text { area. Collected with } \\
\text { stainless steel spatula. }\end{array}$ & $\begin{array}{l}\text { XRFS also by } 3 \text { acid extration } \\
\text { followed by ICP-AES/MS. } 30 \\
\text { elements reported }\end{array}$ \\
\hline $\begin{array}{l}\text { Xinmin et al. } \\
(2006)\end{array}$ & Beijing, China & $\begin{array}{l}\text { Results from this study are very important to protect and enhance } \\
\text { environmental quality. }\end{array}$ & $\begin{array}{l}\mathrm{S}(0-10) 100 \\
\text { mesh sieve (21) } \\
\text { Dust (20) }\end{array}$ & $\begin{array}{l}\text { Soil collected with stainless steel } \\
\text { shovel made of } 4 \text { sub-samples from } \\
\text { corners of a square. Dust collected } \\
\text { at same time from paved road } \\
\text { surface beside street with plastic } \\
\text { broom and stainless steel pan }\end{array}$ & $\begin{array}{l}\mathrm{Hg} \text { determined using Atomic } \\
\text { Fluorescence Spectrometry (AFS) } \\
\text { following aqua regia extraction+pH } \\
\text { \& organic matter (chromic acid } \\
\text { digestion method) }\end{array}$ \\
\hline $\begin{array}{l}\text { Yongming et } \\
\text { al. (2006) }\end{array}$ & Xi'an, China & $\begin{array}{l}\text { To determine concentrations of } 9 \text { heavy metals in urban dust, } \\
\text { identify natural or anthropogenicsources, and to guage the degree of } \\
\text { anthropogenic influence on heavy metal contamination in urban } \\
\text { dusts. }\end{array}$ & $\begin{array}{l}\text { Dust }(<1 \mathrm{~mm}) \\
(65)\end{array}$ & $\begin{array}{l}\text { Dusts collected with plastic dustpan } \\
\& \text { brush over } 1 \mathrm{~m}^{2} \text { area }\end{array}$ & $\begin{array}{l}\text { Four acid extraction followed by } \\
\text { determination of } \mathrm{Ag}, \mathrm{Cr}, \mathrm{Cu}, \mathrm{Mn}, \mathrm{Pb}, \\
\mathrm{Zn} \text { by AAS, As, } \mathrm{Hg} \& \mathrm{Sb} \text { by AFS }\end{array}$ \\
\hline
\end{tabular}

AAS Atomic Absorption Spectometry

AqRE Aqua Regia Extraction

CEC Cation Exchange Capacity

ICP. Inductively Coupled Plasma Atmic Emission Spectometry/mass spectrometry/optical

AES/MSIOES emission spectrometry

LOI Loss-on-Ignition
NAA Neutron Activation Analysis

PAH Polycyclic Aromatic Hydrocarbon

RDS road deposited sediment

S soil

TOC Total Organic Carbon

XRFS X-Ray Fluorescence Spectrometry

Depth of soil sampling given as a range in $\mathrm{cm}$ within brackets in sample media column. Number of samples given in italics within brackets.

\section{Table 1: Summary of some examples of urban geochemical mapping studies from around the world}

$<<<$ may need some editing to fit in Journal - best on two opposite landscape pages) > > > > > 
Table 2: Classification of urban geochemical mapping studies into two groups

\begin{tabular}{|c|c|}
\hline SYSTEMATIC SURVEY & TARGETED SURVEY \\
\hline ENTIRE URBAN AREA & TARGETED LAND USEIAREA \\
\hline $\begin{array}{l}\text { INTERPRETED IN THE CONTEXT OF } \\
\text { REGIONAL BASELINE }\end{array}$ & $\begin{array}{l}\text { INTERPRETED IN THE CONTEXT OF } \\
\text { GUIDELINE VALUES }\end{array}$ \\
\hline UBIQUITOUS SAMPLE MEDIUM & VARIETY OF SAMPLE MEDIA \\
\hline 100s - 1000s samples & 1s - 10s samples \\
\hline $\begin{array}{l}\text { FULL RANGE OF ELEMENTS +l- } \\
\text { organics }\end{array}$ & $\begin{array}{l}\text { SELECTED ELEMENTS } \\
\text { inorganic/organics }\end{array}$ \\
\hline $1 \sim 4$ samples per $\mathrm{km}^{2}$ & $4 \sim 50$ samples per $\mathrm{km}^{2}$ \\
\hline $\begin{array}{l}\text { DONE BY NATIONAL/PUBLIC } \\
\text { ORGANISATIONS }\end{array}$ & $\begin{array}{l}\text { DONE BY RESEARCH } \\
\text { ORGANISATIONS/UNIVERSITIES }\end{array}$ \\
\hline
\end{tabular}

Table 3: UK CLEA Soil Guideline Values (all values in $\mathbf{m g} / \mathbf{k g}$ dry weight soil). Compiled from DEFRA-EA (2002b-h)

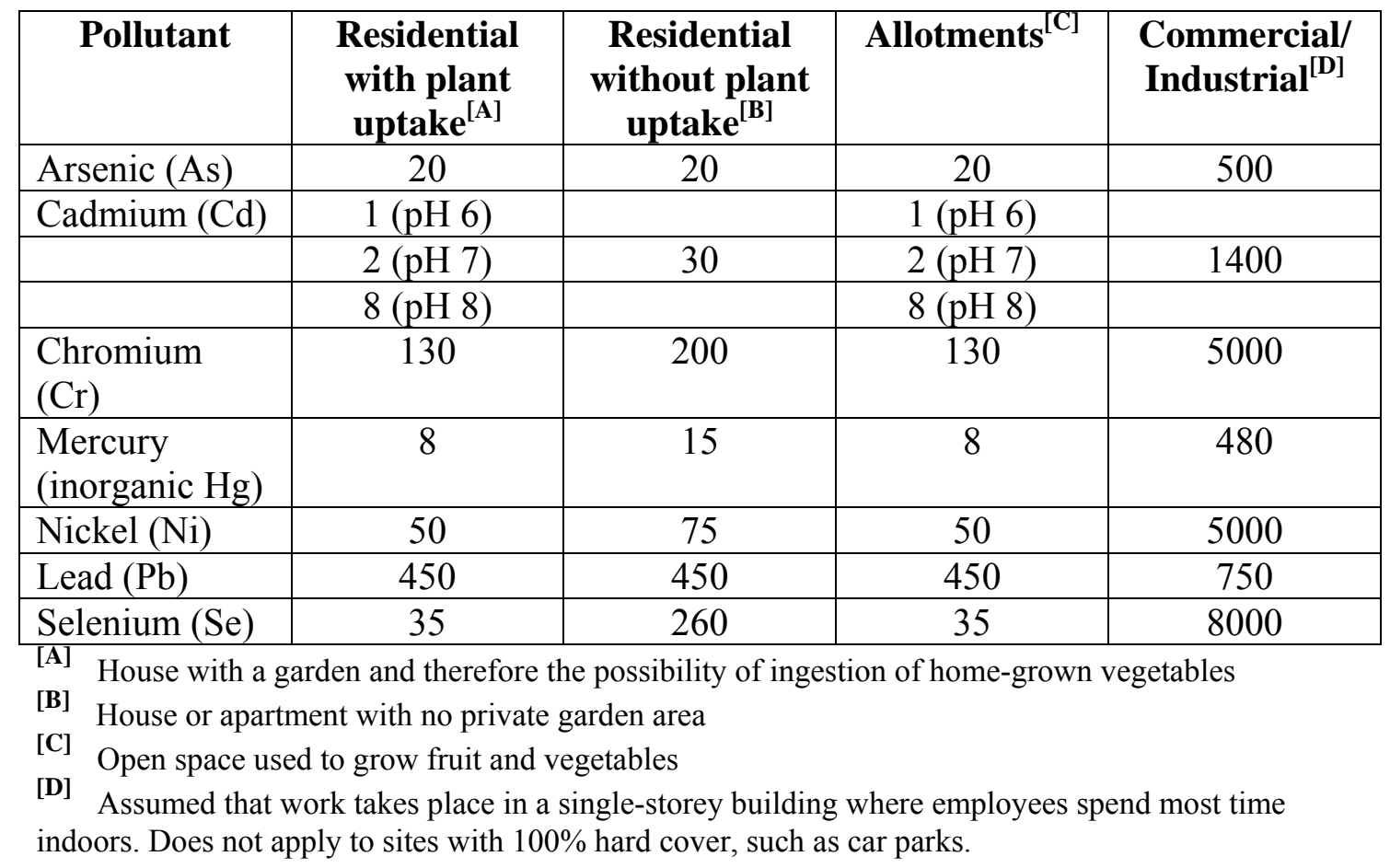

